\title{
Agronomic performance of sweet potato genotypes under management of liming and mineral fertilization
}

Ronaldo Bernardino dos Santos Junior ${ }^{1} \odot$, Tancredo Augusto Feitosa de Souza'®${ }^{1}$,

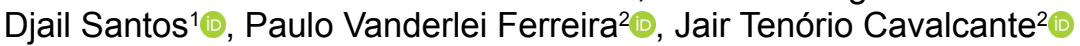

\footnotetext{
1 Universidade Federal da Paraíba, Centro de Ciências Agrárias, Programa de Pós-Graduação em Agronomia, Areia-PB, Brasil. E-mail: bernardino.ronaldo@gmail.com; tancredo_agro@hotmail.com; santosdjail@gmail.com

${ }^{2}$ Universidade Federal de Alagoas, Centro de Ciências Agrárias, Programa de Pós-Graduação em Agronomia, Rio Largo-AL, Brasil. E-mail: paulovanderleiferreira@bol.com.br; jairtc@ig.com.br
}

ABSTRACT: Our aim was to evaluate the agronomic performance, the use of limestone, and NPK fertilizer on sweet potato genotypes during two consecutives agricultural years (2009 and 2010). We conducted the experiment by using a randomized block design with twenty-one treatments (seven genotypes and three combinations of the use of limestone with mixed NPK fertilizer) in three blocks. The studied treatments were a control (no liming and no mineral fertilization), reduced management (liming and no mineral fertilization), and conventional management (liming and mineral fertilization). We evaluated commercial and roots yields, root diameter, root length, and shoot biomass yield. Database was analysed by using analysis of variance (F-test) and Bonferroni test at 5\% of probability. Sergipana Branca genotype had the highest commercial and roots yields, root diameter and root length. Among the studied treatments, both minimum and conventional management promoted increases in all evaluated agronomic variables. The results of this study emphasize the importance of considering using liming and mineral fertilization in high yield farming systems. In family farming systems, however, using limestone becomes a minimum practice of soil fertility management that can improve yield of sweet potatoes while having a low benefit-cost ratio.

Key words: family farming system; Ipomoea batatas L. (Lam); mineral nutrition; soil pH; yield

\section{Desempenho agronômico de genótipos de batata-doce em função do manejo da calagem e adubação mineral}

RESUMO: Objetivou-se neste estudo avaliar o desempenho agronômico, o uso de calcário e NPK em genótipos de batatadoce, nos anos de 2009 e 2010. Foi realizado um experimento utilizando-se o delineamento em blocos casualizados, com vinte e um tratamentos (sete genótipos e três combinações do uso de calcário com NPK) em três blocos. Os tratamentos foram constituídos de controle (Sem calagem e adubação mineral), manejo mínimo (Com calagem e sem adubação mineral), manejo convencional (Com calagem e adubação mineral). Foram avaliados as produtividades comerciais e total de raízes, 0 diâmetro de raízes comerciais, o comprimento de raízes comerciais e a produtividade da biomassa da parte aérea. Os dados foram avaliados por meio de análises de variância (teste F), e teste de Bonferroni a $5 \%$ de probabilidade. 0 genótipo Sergipana Branca apresentou os maiores valores para as produtividades comercial e produtividade total de raízes, diâmetro radicular e comprimento radicular. Entre os manejos estudados, ambos o manejo mínimo e o convencional promoveram incrementos em todos os componentes agronômicos avaliados. Os resultados deste estudo ressaltam a importância de considerar a prática da calagem e a adubação mineral em sistemas de produção em que se busque a obtenção de altas produtividades. Já em sistemas de agricultura familiar regional, a calagem torna-se uma prática mínima de manejo da fertilidade do solo que possa promover melhoria no rendimento de batata-doce com baixa relação custo benefício.

Palavras-chave: agricultura familiar; Ipomoea batatas L. (Lam); nutrição mineral; pH do solo; produtividade 


\section{Introduction}

Sweet potato (Ipomoea batatas (L.) Lam.) is a plant species that has high genotypic variability and because of this, it is grown throughout all of the Brazilian territory and considered as one of the twelve most important agricultural crops worldwide (Cavalcante et al., 2010). The plant is rustic, of wide adaptation, with high drought tolerance, easy to grow and can be used as both human and animal food in the form of tubers and branches, respectively. Industries such as food, fabric, paper, cosmetic, adhesive preparation and fuel alcohol can also use the sweet potato as a raw material (Désiré et al., 2017). Moreover, the tubers have a high nutritional value, considered as an excellent source of energy because it is rich in carbohydrates and has a high content of A and B-complex vitamins, and minerals such as calcium, iron and phosphorus (Silveira et al., 2011).

Developed studies aiming to evaluate the response of different sweet potato genotypes to fertilization (Oliveira et al., 2013; Leonardo et al., 2014; Gibberson et al., 2017) demonstrated that when growing sweet potatoes in medium fertility soils, regardless of the cultivated genotypes, usually there is no response to mineral fertilization. In 2018, the national yield and in the State of Alagoas were 13.99 and 8.95 t ha-1 ${ }^{-1}$, respectively (IBGE 2018). Cavalcante et al. (2010), in an experiment evaluating different sweet potato genotypes in the State of Alagoas, point out that without applying lime and fertilization it is possible to produce a mean of $6.29 \mathrm{t}$ ha $^{-1}$ of commercial roots. Désiré et al. (2017) report that mineral fertilization did not promote increases in the yield of sweet potato genotypes grown in Nigeria. However, it is not clear how these studies performed liming, as studies aimed at evaluating only its isolated effect are scarce and rare in conditions of semi-arid environments.

Therefore, this study was based on the following hypothesis: in medium fertility soils, minimum soil fertility management, by simply applying dolomitic limestone, can promote increases in total and commercial roots of cultivated sweet potato genotypes on highly weathered soils; and that correct liming combined with an appropriate dosage of NPK fertilizer can further increase sweet potato yield. Based on the studies developed by Wang et al. (2015) and Oliveira et al. (2006), we expect, with the application of limestone and mineral fertilizer NPK, obtaining changes in the soil chemical composition (i.e., soil reaction and nutrients availability) and balancing the production of tuberous roots and branches that compose the plant shoot.

With this study, the objective was to evaluate the agronomic performance of sweet potato genotypes developed by SMGPCECA-UFAL subjected to different soil fertility management. To this end, we established an experiment under field conditions for two consecutive years, using 7 genotypes, two of which are widely used by regional farmers, and the other five developed by professionals of the plant breeding field from Federal University of Alagoas (UFAL).

\section{Materials and Methods}

We conducted experiment in the experimental area part of the Agricultural Sciences Center from the Federal University of Alagoas (CECA/UFAL), at the highway North BR-104, km 85, municipality of Rio Largo - AL, in 2009 and 2010. The study area is located at the geographical coordinates 927' $\mathrm{S}$ and $35^{\circ} 27^{\prime} \mathrm{W}$, having means altitude of $127 \mathrm{~m}$, maximum temperature of $290 \mathrm{C}$, minimum of $210 \mathrm{C}$ and annual rainfall of $1267 \mathrm{~mm}$ (Cavalcante et al., 2010).

The local soil is classified as a typical Oxisol (Yellow Dystrophic Latosol, according to Embrapa, 2013), whose chemical analysis in the first studied year (2009) showed the following results: $\mathrm{pH}$ : 5.6 (water); $\mathrm{P}: 20.93 \mathrm{mg} \mathrm{dm}^{-3}$ (Mehlich-1); $\mathrm{K}^{+}: 200.00 \mathrm{cmol}_{\mathrm{c}} \mathrm{dm}^{-3} ; \mathrm{Al}^{3+}: 0.00 \mathrm{cmol}_{\mathrm{c}} \mathrm{dm}^{-3}$; $\mathrm{Ca}^{2+}+\mathrm{Mg}^{2+}: 3.50 \mathrm{cmol}_{\mathrm{c}} \mathrm{dm}^{-3}$; CEC: 7.50; base saturation: 58.0 $\%$. In the second studied year (2010), however, new chemical analyzes were performed, with the experimental area soil having the following characteristics: $\mathrm{pH}$ : 6.0 (water); $\mathrm{P}: 13.70$ $\mathrm{mg} \mathrm{dm}{ }^{-3}$ (Mehlich-1); $\mathrm{K}^{+}: 35.00 \mathrm{cmol}_{\mathrm{c}} \mathrm{dm}^{-3} ; \mathrm{Al}^{3+}: 0.00 \mathrm{cmol}_{\mathrm{c}}$ $\mathrm{dm}^{-3} ; \mathrm{Ca}^{2+}+\mathrm{Mg}^{2+}: 3.80 \mathrm{cmol}_{\mathrm{c}} \mathrm{dm}^{-3}$; CEC: 7.24 ; base saturation: $54.4 \%$. We performed liming only in the first studied year (2009) and before planting the sweet potato genotypes. Limestone quantities were determined according to the soil analysis results observed in the first studied year (2009). We incorporated limestone $\left(1,500 \mathrm{~kg} \mathrm{ha}^{-1}\right)$ into the soil at 90 days prior to the planting. Mineral fertilization, on the other hand, was during the planting, with application of $90 \mathrm{~kg} \mathrm{ha}^{-1}$ of the 6-24-12 (NPK) mixed formula.

We evaluated seven sweet potato genotypes, obtained from the germplasm bank of the Department of Plant Genetic Improvement from the Agricultural Sciences Center at UFAL. Three of them, CL-1, CL-3 and CL-10 were from the Copinha variety; CL-9 was from the Paulistinha Branca variety; CL-6 was from the 60-Dias variety; and two more genotypes, Coquinho and Sergipana Branca, are widely cultivated by regional farmers. We subjected each sweet potato genotype to the following treatments: control (No liming and mineral fertilization), minimal management (liming and no mineral fertilization) and conventional management (liming and mineral fertilization).

We set up the experiment in a randomized block design with twenty-one treatments (seven genotypes and three liming and mineral fertilization managements) and three blocks. Experimental units consisted of three $6.0 \mathrm{~m}$ long furrow with $0.30 \mathrm{~m}$ high each, having fifteen plants per furrow, totaling 45 plants/plot, with a spacing of $0.80 \mathrm{~m} \times 0.40 \mathrm{~m}$. We considered the central furrow as useful area, and excluded one plant from each end, totaling 12 plants. For planting in 2009 and 2010, we used healthy and new branches from plants with 80 days containing between 10 and 12 internodes, of which four were buried at the top of the furrow.

We performed regular weeding in order to maintain the plots free of spontaneous plants. The evaluations were the following: commercial and total roots yields (t ha ${ }^{-1}$ ), commercial roots diameter $(\mathrm{cm})$, commercial roots length $(\mathrm{cm})$ and green mass yield $\left(\mathrm{t} \mathrm{ha}^{-1}\right)$. Shoot and root character 
evaluations took place at 120 days after planting. We obtained total root yield from harvesting 12 plants/plot, it comprising the sum of the yield from commercial and non-commercial roots. We considered commercial roots as those with weight between 100 and $800 \mathrm{~g}$. Diameter and length of commercial roots were taken with a caliper and ruler, respectively. Lastly, we obtained the shoot biomass yield from harvesting the branches from the soil surface.

We submitted the data to the Shapiro-Wilk test in order to test whether they meet a normal distribution, and then subjected them to the analysis of variances. The treatment means comparison were by using the Bonferroni test at the $5 \%$ probability level. Statistical analyzes were all performed by using the free R software (R Core Team, 2018).

\section{Results and Discussion}

We observed significant differences for the variables of commercial roots yield $\left(F_{12.40}=9.12, p<0.01\right)$ and total yield $\left(F_{12.40}=12.23, p<0.01\right)$ regarding the interaction genotype $\mathrm{x}$ limestone management (Figure 1). We also observed that the Sergipana Branca genotype was the only one that had higher commercial and total roots yields, when subjected to the conventional management. In the minimum management, the genotypes $\mathrm{CL}-3$ and $\mathrm{CL}-6$ were the ones with the highest commercial roots yield (Figure $1 \mathrm{~A}$ ); and genotypes $\mathrm{CL}-1, \mathrm{CL}-3$ and CL-6 showed the highest total yield (Figure 1B). On the other hand, the control treatment had lower yields than treatments with soil fertility management for all evaluated genotypes, indicating that all genotypes were responsive to the application of both dolomitic limestone and mixed mineral fertilizer and, consequently, the possibility of obtaining yield gains with applying both soil fertility management practices (Rós et al., 2014). These results support the initial hypothesis of this study, that even in conditions of medium fertility in highly weathered soils, the correct application of limestone associated with mineral fertilizer can bring positive benefits in the total and commercial roots yields of sweet potatoes (Oliveira et al ., 2013; Leonardo et al., 2014; Gibberson et al., 2017). Regarding the results of commercial and total root yields, Cavalcante et al. (2010) found similar results in eleven sweet potato genotypes grown without fertilization and liming in the municipality of Junqueiro, $A L$, with means ranging from $4.1 \mathrm{t} \mathrm{ha}^{-1}$ for non-commercial roots yield to $7.8 \mathrm{t}$ $\mathrm{ha}^{-1}$ for total yield. Essilfie et al. (2016) evaluated the influence of mineral and organic fertilization on sweet potato yield, and observed that the highest $\left(4.58 \mathrm{t} \mathrm{ha}^{-1}\right)$ was product of the application of 20,40 and $40 \mathrm{~kg} \mathrm{ha}^{-1}$ of $\mathrm{N}, \mathrm{P}$ and $\mathrm{K}$, respectively. In these scenarios, yield was significantly lower than the national mean (13.99 $\mathrm{t} \mathrm{ha}^{-1}$ ) due to the following facts: i) low potassium content in the soil and absence of practices related to topdressing fertilization with potassium fertilizers (i.e., potassium chloride); ii) prolonged water stresses during the initial plants development; and iii) absence of soil organic matter management practices (Désiré et al. 2017). Foloni et al. (2013) conducted an experiment with $\mathrm{N}$ and $\mathrm{K}$ dosages of 100 and $120 \mathrm{~kg} \mathrm{ha}^{-1}$, respectively, and obtained yield of $24,9 \mathrm{t} \mathrm{ha}^{-1}$.
A.
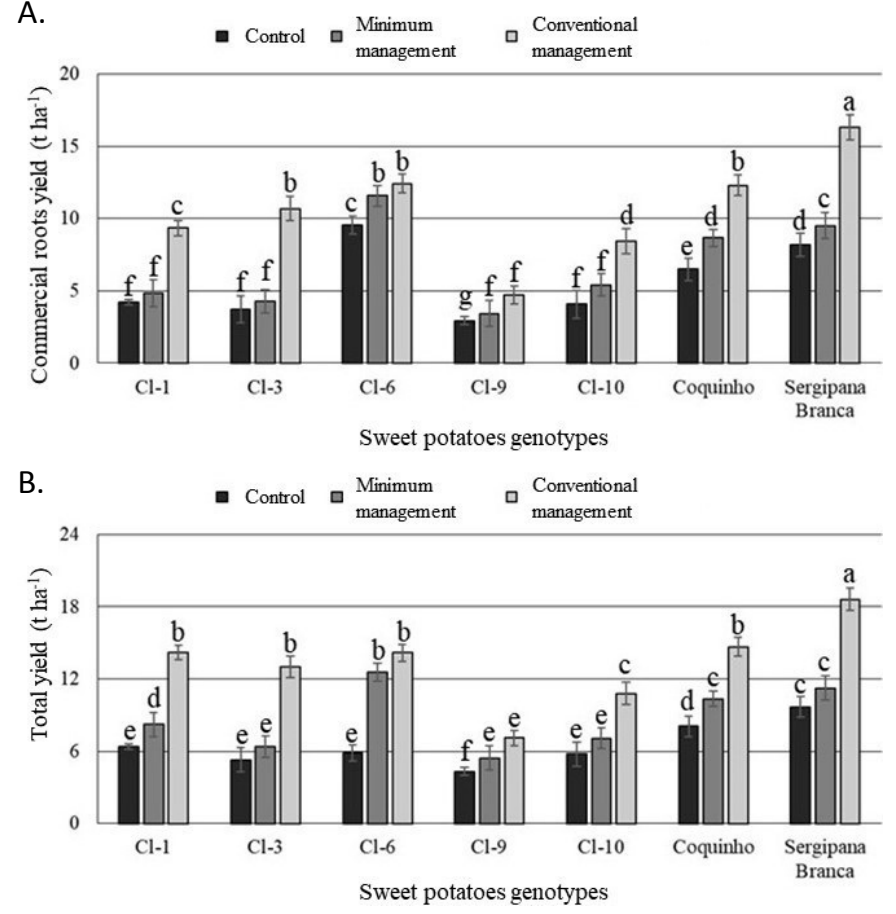

Figure 1. Commercial roots (A) and total (B) yields of different sweet potato genotypes subjected to different managements (mean \pm standard deviation, $N=62$ ) in 2009 and 2010. Control: No liming and no mineral fertilization; Minimum Management: Liming and no mineral fertilizer; and Conventional Management: Liming and mineral fertilizer. Bars with the same letters do not differ by Bonferroni test at $5 \%$ probability.

Meanwhile, Cecílio Filho et al. (2016), found maximum yield of $38 \mathrm{tha}^{-1}$ with the application of $87 \mathrm{~kg} \mathrm{ha}^{-1}$ of $\mathrm{K}_{2} \mathrm{O}$.

On the other hand, for the variables of root diameter and length, we found only significant differences between the genotypes $\left(F_{6.40}=21.81, p<0.01\right.$ e $F_{6.40}=4.41, p<0.05$, respectively); and between the soil fertility treatments $\left(F_{2.40}=12.90 p<0.01 ; F_{12.40}=11.05, p<0.01\right.$, respectively $)$. There were no significant effects of the interaction between genotypes and soil fertility management. The genotypes with the largest diameter and root length were CL-1 and Sergipana Branca (Figure 2A). In relation to the fertility management treatments, we observed that conventional management with the application of limestone and mineral fertilizer promoted the highest values of diameter and length of the roots from the sweet potato genotypes (Figure 2B). Cavalcante et al. (2010) observed similar results for the Sergipana Branca genotype, with mean diameter and root length of 5.34 and $14.59 \mathrm{~cm}$, respectively. Application of limestone, a common agricultural practice in correcting soil acidity, promotes favorable conditions (e.g., changes in $\mathrm{pH}$, in the preservation and decomposition of organic matter and nutrients availability) for the root development of cultivable plants (Wang et al., 2015). In environments with favorable $\mathrm{pH}$ and without the exchangeable aluminum presence, the roots show excellent growth and development, and, according to Leonardo et al. (2014), determining root diameter and length are excellent 

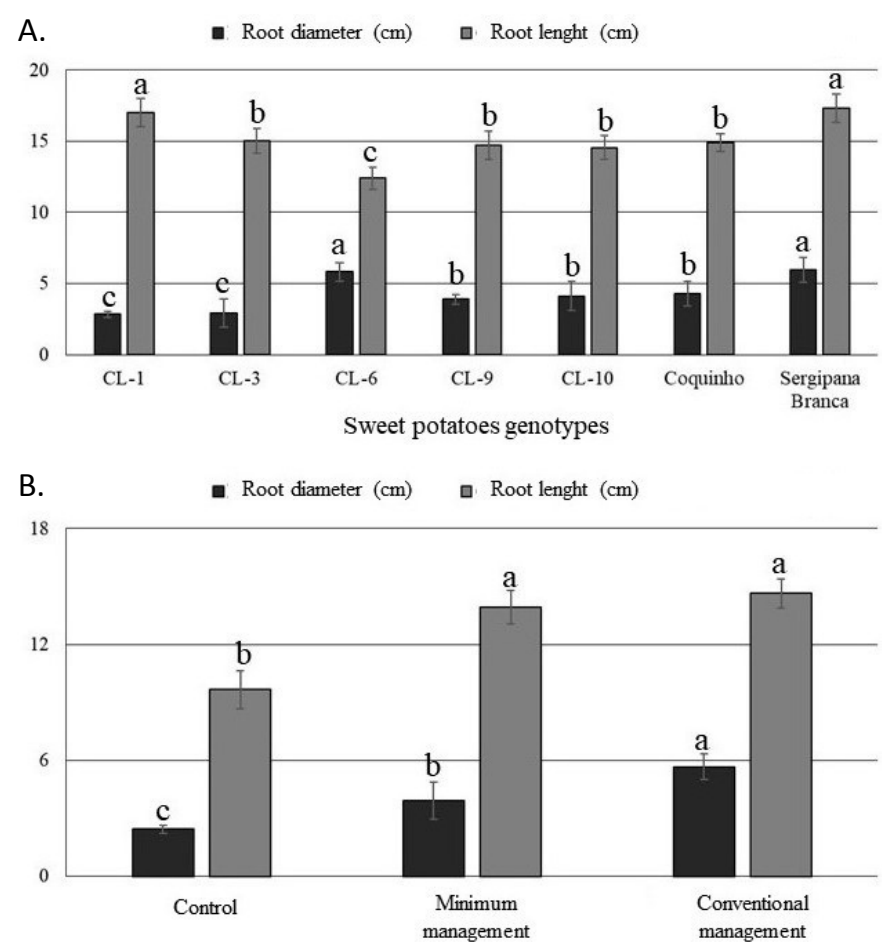

Figure 2. Root diameter $(\mathrm{cm})$ and length $(\mathrm{cm})$ regarding the different genotypes of sweet potato $(\mathrm{A})$; and the different soil fertility managements (B) (mean \pm standard deviation, $N$ $=62$ ) in 2009 and 2010. Control: No liming and no mineral fertilization; Minimum Management: Liming and no mineral fertilizer; and Conventional Management: Liming and mineral fertilizer. Bars with the same letters do not differ by Bonferroni test at $5 \%$ probability.

indicators of favorable edaphic conditions for the development of tuberous roots. Pushpalatha et al. (2017) report that correct doses of provided NPK in mineral fertilization, when combined with liming, promote improvement in plant growth, physiological activity and photosynthetic rates that can all lead to an increase in weight, diameter, length and number of sweet potato tuberous roots.

We observed significant effects in the interaction between the genotypes and the soil fertility management $\left(F_{12.40}=19.53\right.$, $p<0.01$ ) in the production of the shoot biomass from sweet potatoes genotypes. Genotype $\mathrm{CL}-10$ was the one that had the highest shoot biomass yield. We also observed that all evaluated genotypes were responsiveness to the treatments of soil fertility management, except for the CL-6 genotype, which did not show shoot yield variations regarding the soil fertility management. Désiré et al. (2017) found similar results when evaluating the shoot biomass production from different genotypes of sweet potato in function of the application of mineral and organic fertilizers in sandy soils. Several authors have demonstrated that mineral NPK fertilization promotes the increase in the vegetative growth in various plant species by enhancing the absorption of available nutrients such as nitrogen, phosphorus and potassium (Wang et al., 2015; Mahjourimajd et al., 2016; Drakopoulos et al., 2016). Santos Neto et al., (2016) conducted an essay with $\mathrm{N}$ dosages in

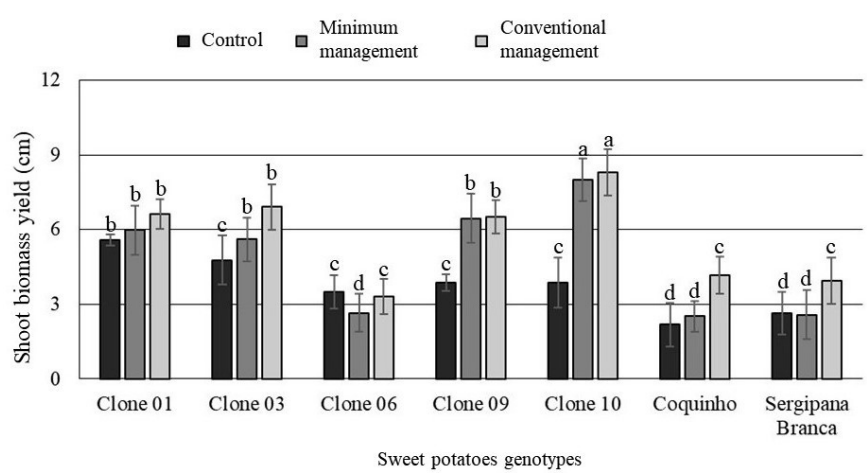

Figure 3. Shoot biomass yield ( $\mathrm{tha}^{-1}$ ) from different genotypes of sweet potato de subjected to different managements (mean \pm standard deviation, $N=62$ ) in 2009 and 2010. Control: No liming and no mineral fertilization; Minimum Management: Liming and no mineral fertilizer; and Conventional Management: Liming and mineral fertilizer. Bars with the same letters do not differ by Bonferroni test at $5 \%$ probability.

sweet potatoes clones and obtained shoot yield of $11.64 \mathrm{t} \mathrm{ha}^{-1}$ with the $\mathrm{N}$ dosage of $240 \mathrm{~kg} \mathrm{ha}^{-1}$.

\section{Conclusions}

The Sergipana Branca genotype had the highest commercial roots and total yields, as well as the highest values of diameter and length of tuberous roots.

CL-10 was the genotype that had the highest shoot biomass production.

There was influence of fertility management on all studied agronomic variables.

Genotypes CL-6, CL-1 and Sergipana Branca showed high responsiveness to the application of dolomitic limestone and NPK mineral fertilization even in the soil with medium fertility.

Under field conditions, reduced management showed satisfactory results of tuberous roots and shoot yield of sweet potato genotypes, and that regional family farmers can use it with a lower cost/benefit ratio in comparison to conventional management where, in addition to liming, NPK mineral fertilizer would also be necessary.

The results of this study emphasize the importance of considering minimum practices of soil fertility management in order to obtain significant yield while minimally damaging the edaphic environment.

\section{Literatura citada}

Cavalcante, M.; Ferreira, P. V.; Paixão, S. L.; Costa, J. G. da; Pereira, R. G.; Madalena, J. A. Desempenho agronômico, dissimilaridade genética e seleção de genitores de batata doce para hibridização. Revista Brasileira de Ciências Agrárias, v.5, n.4, p.485-490, 2010. https://doi.org/10.5239/agraria.v5i4.816.

Cecílio Filho, A. B.; Nascimento, S. M. C.; Silva, A. S. N.; Vargas, P. F. Agronomic performance of sweet potato with different potassium fertilization rates. Horticultura Brasileira, v. 34, n. 4, p.588-592, 2016. https://doi.org/10.1590/s0102-053620160421. 
Désiré, T. V.; Vivien, N. G.; Claude, S. Evaluation of different sweet potato varieties for growth, quality and yield traits under chemical fertilizer and organic amendments in sandy ferralitic soils. Academic Journals, v.12, n.48, p.3379-3388, 2017. https:// doi.org/10.5897/AJAR2017.12675.

Drakopoulos, D.; Scholberg, J. M. S.; Lantinga, E. A.; Tittonell, P. A. Influence of reduced tillage and fertilization regime on crop performance and nitrogen utilization of organic potato. Organic Agriculture, v.6, n.2, p.75-87, 2016. https://doi.org/10.1007/ s13165-015-0110-x.

Empresa Brasileira de Pesquisa Agropecuária - Embrapa. Centro Nacional de Pesquisa de Solos. Sistema brasileiro de classificação de solos. 3.ed. Brasília: Embrapa, 2013. 353 p.

Essilfie, M. E.; Ofosu-anim, J.; Dapaah, H. K.; Blay, E. T.; Norman, J. C. Yield and root quality of two sweetpotato (Ipomoea batatas [L.] Lam) varieties as influenced by chicken manure, inorganic fertilizer and storage methods. American Journal of Experimental Agriculture, v. 11, n. 2, p.1-19, 2016. https://doi.org/10.9734/ AJEA/2016/22446.

Foloni, J. S. S.; Corte, A. J.; Corte, J. R. N.; Echer, F. R.; Tiritan, C. S. Adubação de cobertura na batata-doce com doses combinadas de nitrogênio e potássio. Semina, v. 34, n. 1, p.117-126, 2013. https://doi.org/10.5433/1679-0359.2013v34n117.

Gibberson, D. I.; Joshua, O. S. D.; Ato, B. P.; Emmanuel, S. A.; Justice, $\mathrm{O}$. Productivity and quality of orange fleshed sweet potato (Ipomoea batatas (L) Lam) as affected by irrigation and fertilizer application. Scholars Journal of Agriculture and Veterinary Sciences, v.4, n.2, p.58-67, 2017. https://doi.org/10.21276/ sjavs.2017.4.2.4.

Instituto Brasileiro de Geografia e Estatística - IBGE. Pesquisas agropecuárias. 3.ed. Rio de Janeiro: IBGE, 2018. (IBGE. Série relatórios metodológicos, v.6). https://biblioteca.ibge.gov.br/ visualizacao/livros/liv101552.pdf. 12 Out. 2018. Leonardo, F. de A.P.; Oliveira, A.P. de; Pereira, W.E.; Silva, O.P.R.; Barros, J.R.A. Rendimento da batata-doce adubada com nitrogênio e esterco bovino. Revista Caatinga, v. 27, n. 2, p.18-23, 2014. https:// periodicos.ufersa.edu.br/index.php/caatinga/article/view/2692/ pdf_110. 12 Out. 2018.
Mahjourimajd, S.; Kuchel, H.; Langridge, P.; Okamoto, M. Evaluation of Australian wheat genotypes for response to variable nitrogen application. Plant Soil, v.399, n.1-2, p.247-255, 2016. https://doi. org/10.1007/s11104-015-2694-z.

Oliveira, A. P. de; Gondim, P. C.; Silva, O. P. R. da; Oliveira, A. N. P. de; Gondim, S. C.; Silva, J. A. Produção e teor de amido da batata-doce em cultivo sob adubação com matéria orgânica. Revista Brasileira de Engenharia Agrícola e Ambiental, v. 17, n.8, p.830-834, 2013. https://doi.org/10.1590/S1415-43662013000800005.

Oliveira, A. P. de; Silva, J. E. L. da; Pereira, W. E.; Barbosa, L. J. N.; Oliveira, A. N. P. Características produtivas da batata-doce em função de doses de $\mathrm{P}_{2} \mathrm{O}_{5}$, de espaçamento e de sistemas de plantio. Ciência e Agrotecnologia, v. 30, n. 4, p. 611-617, 2006. https://doi.org/10.1590/S1413-70542006000400003.

Pushpalatha, M.; Vaidya, P. H.; Adsul, P. B. Effect of graded levels of nitrogen and potassium on yield and quality of sweet potato (Ipomoea batatas L.). International Journal of Current Microbiology and Applied Sciences, v.6, n.5, p.1689-1696, 2017. https://doi.org/10.20546/ijcmas.2017.605.183.

$\mathrm{R}$ Core Team. R: A language and environment for statistical computing. Vienna: R Foundation for Statistical Computing, 2018. https:// www.R-project.org. 07 Sep. 2018.

Rós, A. B.; Narita, N.; Hirata, A. C. S.; Produtividade de batata-doce e propriedades físicas e químicas de solo em função de adubação orgânica e mineral. Semina: Ciências Agrárias, v. 35, n. 1, p. 205 214, 2014. https://doi.org/10.5433/1679-0359.2014v35n1p205.

Santos Neto, A. S.; Silva, T. O.; Blank, A. F.; Silva, J. O.; Araújo Filho, R. N. Produtividade de clones de batata doce em função de doses de nitrogênio. Horticultura Brasileira, v. 35, n. 3, p.445-452, 2017. https://doi.org/10.1590/s0102-053620170322.

Silveira, L. R. da; Chiesa, V. B.; Tavares, I. B.; Souza, R. C. de; Silveira, M. A. da; Alves, D. G.; Oliveira Junior, W. P. de. Caracterização físico-química de clones de batata-doce de polpa alaranjada nas condições de Palmas-TO. Estudos, v. 38, n. 2, p. 365-380. 2011. https://doi.org/10.18224/est.v38i2.2198.

Wang, W. Q.; Sardans, J.; Wang, C.; Zeng, C. S.; Tong, C.; Asensio, D.; Peñuelas, J. Ecological stoichiometry of $\mathrm{C}, \mathrm{N}$, and $\mathrm{P}$ of invasive Phragmites australis and native Cyperus malaccensis species in the Minjiang River tidal estuarine wetlands of China. Plant Ecology, v.216, n.6, p.809-822, 2015. https://doi.org/10. 1007/s11258-015-0469-5. 